\title{
Issues of state support for non-governmental non-profit organizations in Uzbekistan
}

\section{Bekzod NARIMANOV ${ }^{1}$, Aycholpan DUISHEEVA ${ }^{2}$}

Tashkent State Law University

Kyrgyz-Russian Slavic University

\begin{tabular}{l} 
ARTICLE INFO \\
\hline Article history: \\
Received June 2021 \\
Received in revised form \\
20 June 2021 \\
Accepted 25 July 2021 \\
Available online \\
25 August 2021 \\
\hline Keywords: \\
NGO, \\
public control, \\
social entrepreneurship, \\
socially beneficial status, \\
tax benefits, \\
social partnership.
\end{tabular}

ABSTRACT

This article examines the legal mechanisms of state support for NGOs on the basis of new trends, such as the recognition of NGOs as socially useful, social entrepreneurship, social partnership, based on foreign experience and scientific and theoretical views of scientists. As a result of the study, proposals will be put forward to support non-governmental non-profit organizations and social partnership in Uzbekistan.

2181-1415/@ 2021 in Science LLC.

This is an open access article under the Attribution 4.0 International (CC BY 4.0) license (https://creativecommons.org/licenses/by/4.0/deed.ru)

\section{Ўзбекистонда нодавлат нотижорат ташкилотларини давлат томонидан қўллаб-қувватлаш масалалари}

\section{Калит суцзлар:}

HHT,

жамоатчилик назорати, ижтимоий тадбиркорлик, ижтимоий фойдали холат, солиқ имтиёзлари, ижтимоий шериклик.

\section{АННОТАЦИЯ}

Ушбу мақолада ННТларни ижтимоий фойдали, ижтимоий тадбиркорлик, ижтимоий шериклик сифатида эътироф этиш каби янги тенденцияларга асосланган НHТларни қўллаб-қувватлашнинг хуқуқий механизмлари, хорижий тажриба ва олимларнинг илмий-назарий қарашлари асосида ўрганилган. Тадқиқот натижалари асосида Ўзбекистонда нодавлат нотижорат ташкилотларини ва ижтимоий шерикликни қўллаб-қувватлаш бўйича таклифлар ўртага ташланган.

\footnotetext{
${ }^{1} \mathrm{PhD}$ in Law, Tashkent State Law University, Tashkent, Uzbekistan.

E-mail: narimanovbekzod84@gmail.com.

${ }^{2}$ PhD in Law, Kyrgyz-Russian Slavic University, Byshkek, Kyrgyz Republic.

E-mail: aycholpanduisheeva@gmail.com.
} 


\section{Вопросы государственной поддержки негосударственных неправительственных некоммерческих организаций в Узбекистане}

\author{
Ключевые слова: \\ $\mathrm{HHO}$, \\ общественный контроль, \\ социальное \\ предпринимательство, \\ социально-выгодный \\ статус, \\ налоговые льготы, \\ социальное партнерство.
}

\begin{abstract}
АННОТАЦИЯ
В данной статье рассматриваются правовые механизмы государственной поддержки НHO на основе новых тенденций, таких как признание НHО общественно полезными, социальное предпринимательство, социальное партнерство, основанные на зарубежном опыте и научнотеоретических взглядах ученых. По итогам исследования будут выдвинуты предложения по поддержке негосударственных некоммерческих организаций и социального партнерства в Узбекистане.
\end{abstract}

In international practice, the implementation of social partnership between nongovernmental organizations and government agencies has been identified as one of the main priorities in the formation of civil society in general and the effectiveness of its institutions.

It is no coincidence that in his Address to the Parliament on January 20, 2020, the President said that "in order to increase the practical effectiveness of reforms, to promote new initiatives on the ground, we must make our people more active and proactive".

In our opinion, the following goals can be achieved in Uzbekistan through state support of non-governmental non-profit organizations and improvement of legal mechanisms of social partnership:

- implementation of socially useful projects such as poverty reduction, job creation, human rights;

- Improving the position of our country in prestigious international rankings through the development of the institute of "people's diplomacy";

- Improving a strong public oversight mechanism by NGOs using effective and efficient forms of control, such as "public hearings", "public expertise", and "public monitoring";

- Implementation of the principle of "Society - the initiator of reforms" through the active participation of non-governmental non-profit organizations in the development and discussion of draft regulations.

We will try to focus on strategic issues, as the legal mechanism for supporting nongovernmental non-profit organizations in our country is described in detail in paragraph 1.3 on a historical step-by-step basis.

In covering this paragraph, we aim to cover three main aspects of government support for NGOs:

1. Prospects for the legal regulation of the recognition of a non-governmental nonprofit organization as socially useful;

2. Prospects for improving the legal mechanisms of the institution of social partnership with the participation of non-governmental organizations;

3. Strategy for the development of the non-governmental sector in Uzbekistan on the example of the National Association of Non-Governmental Organizations. 
Today, in most developed countries, especially in Brazil, Germany, and the United States, support for NGOs is provided through the recognition of these organizations as "socially useful".

Recognizing a nonprofit organization as "socially useful" or "socially oriented" was a process that began in Europe in the 17th century, and in 1601 a list of charitable purposes for nonprofits was approved in the United Kingdom under the Charter of Charitable Purposes.

According to D. Moor, the recognition of a non-governmental non-profit organization as socially useful consists of the following 6 organizational and legal bases: $i$ The formation of the regulatory framework for the recognition of socially useful; the procedure for recognizing it as socially useful; decision-making bodies in this area; registration or certification procedure; state-guaranteed benefits for a socially useful organization; the order of accountability of socially useful organizations [4].

S.N. According to Nemgirova, the effective operation of socially oriented NGOs will be an important factor in ensuring the stability of the region [5].

E.K. As Guseynov rightly points out, empowering non-governmental organizations to provide basic social protection services is a very dangerous and time-consuming process that requires a restructuring of the entire mechanism of social policy implementation. This "transformation" is more promising for additional social protection services, significantly improving social services and expanding the number of services provided [6].

It is known from foreign experience that information on the activities of nongovernmental non-profit organizations engaged in sponsorship and charitable activities is published in a number of independent sources. Various rating agencies analyze the activities of funds and publish their ratings. This situation also serves as a kind of reporting for those who carry out sponsorship and charitable activities.

Recognition of social benefits and the provision of tax benefits are enshrined in the Tax Code in countries such as Germany and the Netherlands, and this model takes precedence in the application of administrative law, as recognition of social benefits is the subject of taxation. A shortcoming of this model is the impossibility of legal regulation of a non-profit organization that is recognized as socially beneficial in tax legislation [7].

According to another model, the recognition of a non-profit organization as socially beneficial is regulated by certain framework laws in countries such as Bosnia, Bulgaria, and Romania. The disadvantage of this model is the procedure for recognizing public associations, foundations and similar non-governmental non-profit organizations as socially useful in separate legislation for each organizational and legal form. This situation leads to different approaches to the application of socially beneficial status of nongovernmental non-profit organizations for different legal forms [8].

Therefore, in order to ensure a single legal mechanism for recognition of social benefits in some countries, Hungary adopted the Law on Recognition of Social Benefit in 1997, Lithuania in 2002 adopted the Law on Charity and Sponsorship, and Poland adopted the Law on Socially Beneficial Activities and Volunteerism. .

This model is characterized by regulating all aspects of the recognition of a nongovernmental non-profit organization as socially useful, such as granting this status, applying its criteria, benefits and their application, obligations and the procedure for their implementation. 
Recognized as socially useful in all the European countries analyzed above, amateur sports, arts, support for people with disabilities, refugee assistance, charity, human rights, consumer protection, culture, democracy, environmental protection, education, activities such as combating racism, health, humanitarian aid, protection of historical monuments, medical care, protection of children, youth and socially vulnerable persons, religious, scientific, social integration, social security.

In our opinion, the experience of granting socially beneficial status to nongovernmental non-profit organizations shows that they will have the opportunity to enter the additional market for social services. It should also be noted that social services provided by non-governmental non-profit organizations are cheaper than those provided by government agencies, and it is easier for them to attract extra-budgetary funds, grants and establish cooperation.

In addition, unlike government agencies, one of the strengths of the nonprofit sector is flexibility, which means that they are willing to work on weekends, have more opportunities to develop innovative services, are free of bureaucratic rules, and involve many non-financial people (volunteers).

D. Morris, a scholar who has studied the process of recognizing the nongovernmental sector as socially useful in most developed countries, argues that the status of socially useful should serve the public interest. The commissions for the recognition of social benefits by the competent authorities in different countries must provide this status on the basis of three factors: the organization must bring to society a clearly visible social benefit recognized by members of society; in order to be socially useful, a group of individuals must enjoy the results of this social activity sufficiently. socially useful activities should be of a completely random nature when directed at individuals. This is to prevent conflicts of interest [1].

Different ratios are given in different countries in determining socially useful activities. In the Netherlands, when a non-governmental organization is recognized as socially useful, more than $50 \%$ of the organization's activities must be considered socially useful. In France, in order for an organization to be recognized as socially useful, the organization is required to perform at least 1 social service on a statutory list [11].

In most countries, the tax authorities grant the "third sector" socially useful status. The analysis showed that in granting this status, the legislation does not pay attention to the organizational and legal forms of the organization. Denmark, Finland, Germany, Ireland, the Netherlands, Portugal and Sweden follow this procedure. In Denmark, the tax authorities announce to the general public at the end of each year which organizations have socially beneficial status.

In Germany, socially useful status is provided by local tax authorities and every 3 years organizations are inspected for socially useful subject. In the Netherlands, there is a notification procedure for finding socially useful, and this procedure is aimed at preventing potential administrative legal disputes. In the Netherlands, the main manifestation of the recognition of social benefits is the open publication of the organization's annual reports on the basis of special standards [12].

In our opinion, this fact, especially the fact that the sponsoring organization has this status, serves as a reliable source in the implementation of charitable funds of the donor organization and individuals. In addition, the disclosure of the activities of independent rating agencies and the publication of their ratings by independent rating agencies outside the tax authorities will prevent cases such as various corruption and conflicts of interest. 
Recognition as socially useful in Bulgaria is carried out by the Ministry of Justice of the non-profit organization by submitting an application with the relevant documents attached. If the Ministry of Justice refuses to grant socially useful status, the NGO has the right to appeal to the Supreme Administrative Court against the decision of the administrative body [13].

In our opinion, the appointment of a single body authorized to provide socially useful status can lead to the subsequent deprivation of this status of non-governmental non-profit organizations for political reasons. Therefore, in Hungary and Poland, the judiciary is empowered to grant socially useful status and special certificates. In France, too, this power is vested in the Council of State, the highest administrative court.

Based on the above analysis, it is expedient to develop criteria and methodologies for evaluating the activities of non-governmental non-profit organizations in the Republic of Uzbekistan, taking into account their contribution to the solution of socio-economic issues and the development of society.

These criteria are aimed at recognizing a non-governmental non-profit organization as socially useful and determining the level of social utility based on foreign experience. The transfer of this authority to the Public Chamber, established on the basis of the Decree No. PF-5980 of April 16, 2020 "On the establishment of the Public Chamber under the President of the Republic of Uzbekistan" is a right thing to do.

Today, public chambers and their analogues have been established in more than 80 countries. They are constitutional advisory bodies in some countries and have advisory status in others. We can see that these structures are formed in the form of councils or in the form of various commissions, groups, advisory meetings, etc. [16].

In our opinion, the following goals will be achieved by giving this structure a socially useful status to a non-governmental non-profit organization:

The Public Fund for Support of Non-Governmental Organizations and Other Civil Society Institutions under the Oliy Majlis of the Republic of Uzbekistan pays special attention to fairness, transparency and efficiency in providing subsidies, grants and social orders from the state budget.

There will be an opportunity for socially recognized organizations to cooperate in lawmaking, implementation of social projects, development of the institute of "people's diplomacy".

The Public Chamber assists non-governmental non-profit organizations in cooperating with other state bodies, including higher and local representative bodies, in addressing systemic problems in various spheres of state and society, as well as in the use of targeted social order and social partnership mechanisms.

At the same time, the main criteria for the effectiveness and efficiency of civil society institutions are the number of socially useful projects, proposals to improve the legislation in the field and the relevant changes in the work process and legislation, the level of activity in public oversight. These criteria and the rating of non-governmental organizations should be made available to all taxpayers online on the basis of the principles of openness and transparency on the electronic platform.

In the context of the coronavirus pandemic faced by all mankind, social partnership has once again proved to be the most necessary social, political and legal institution for the development of the state and society. In the example of the most powerful states, we have seen that the state alone is powerless to combat problems such as the pandemic without the participation of society and the general public. 
On the history of social partnership Sh. Yakubov acknowledges that social partnership, formed and developed on the basis of historical periods, was a transformation into social partnership in the twentieth century [17].

According to the experience of foreign countries, in the UK and Canada, the government can be regulated by certain agreements and arrangements for cooperation with the non-governmental sector on social partnership. In countries such as Germany, South Korea, and Japan, the legal mechanism of government social partnership with the non-governmental sector is based on the basic principles set out in the Basic Law. That is, in these countries, social partnership is not regulated by a separate law.

Dedicated to the social partnership of NGOs with government agencies, M.S. Haque [18], D.A. Bräutigam, M. Segarra [19], P. Willetts, C.C. Millar [21] and a number of other research studies can be cited.

T.B. Matibaev noted that in the middle of the twentieth century, the theory of social contract was replaced by the theory of social partnership, and its theoretical conceptual theory was formed on the basis of the ideas of social movement, social solidarity, social harmony, social cohesion [22].

M. According to Tukhtaeva, the law provides for the interaction of civil society institutions, first of all, with government agencies in the social, economic and humanitarian spheres [23].

Sh. According to Yakubov, the adoption of this law established a legal mechanism for all government agencies to enter into social partnerships with non-governmental nonprofit organizations and other institutions of civil society [24].

In the Address of the President of the Republic of Uzbekistan Sh. Mirziyoyev to the Oliy Majlis on January 24, 2020, it would be expedient for non-governmental non-profit organizations and other civil society institutions to draw the attention of government agencies to the problems facing the population.

To do this, we need to expand social partnerships with non-governmental non-profit organizations at the national and regional levels and increase grants and social orders. Ministries and agencies should also expand the work of such social partnerships without sitting as spectators on the sidelines. Therefore, it is necessary to improve the activities of the Public Fund for Support of Non-Governmental Organizations and Other Civil Society Institutions under the Oliy Majlis [25].

In accordance with Article 58 of the Constitution of the Republic of Uzbekistan, interference of state bodies and officials in the activities of public associations, as well as interference of public associations in the activities of state bodies and officials is not allowed.

A. Saidov noted that social partnership has not become an effective mechanism of cooperation between government agencies and non-governmental organizations aimed at solving a wide range of social problems of citizens, especially the real promotion of youth initiatives and modern ideas [26].

The Law of the Republic of Uzbekistan "On Social Partnership" No. ZRU-376 is a special document adopted to determine the legal mechanisms of social partnership.

As Sh. Yakubov rightly points out, this law has become a narrow-minded law regulating only the relations between the Public Fund for Support of Non-Governmental Organizations and Civil Society Institutions under the Oliy Majlis and non-governmental organizations [27]. 
In addition, Karimova studied the activities of the Public Commission for Social Partnership in Tashkent city and region during the research and noted that the tasks were not fulfilled at all and in general the structure is almost non-existent in practice [28].

According to the amendment to Article 21 of the Law "On Social Partnership" in accordance with the Law of the Republic of Uzbekistan dated September 14, 2017 No. ZRU446, public authorities can directly order non-governmental non-profit organizations at the expense of extra-budgetary funds to address social issues.

Resolution of the Cabinet of Ministers of the Republic of Uzbekistan dated February 23, 2018 No 135 approved the Regulation on the procedure for issuing state social orders by public administration bodies for the implementation of projects of social and social significance.

According to the amendments to this legislation, public administration bodies have been able to address social issues within the scope of their tasks and functions in an efficient and cost-effective manner by directly issuing state social orders to nongovernmental non-profit organizations at the expense of extra-budgetary funds.

However, in practice, the experience of public administration in addressing social issues within its tasks and functions in an efficient and cost-effective manner to nongovernmental non-profit organizations at the expense of extra-budgetary funds is almost never used.

One of the reasons for this is the fact that public authorities are not fully aware of the opportunities and benefits of this institution.

Therefore, it is proposed to organize regular seminars and trainings for senior government officials on the opportunities and benefits of this institution by the Ministry of Justice and the Public Chamber.

The author of many scientific researches in this field Sh. Yakubov proposes to improve the legal mechanism of social partnership, including private entrepreneurship in social partnership, sharply reduce government interference in the work of collegial bodies on social partnership, decentralization of funding for the "third sector" [29].

According to Article 4 of the Law on Non-Governmental Organizations, interference in the activities of state bodies and their officials by non-governmental non-profit organizations, as well as interference in the activities of state bodies and their officials by non-governmental non-profit organizations is prohibited.

These provisions are reflected in Article 5 of the Law on Guarantees for the Activities of Non-Governmental Organizations.

However, the legislation does not provide for liability for obstruction or interference with the lawful activities of non-governmental non-profit organizations.

Accordingly, it is proposed to establish administrative liability for obstruction or interference in the legal activities of NGOs and to strengthen the legal framework for the National Association of NGOs in this process to appeal to the competent authorities, including the courts and other proceedings.

The role of the National Association of Non-Governmental Organizations of Uzbekistan (NAOO) is very important in defining a strategy for further improving the role of NGOs in the life of the state and society in Uzbekistan. The Association is one of the largest public organizations in the country, established in 2005 at the initiative of 150 nongovernmental non-profit organizations operating in the country and regions. Its main goal is to provide full support to non-governmental non-profit organizations and further liberalize and democratize their public life, build a free and open strong civil society, and further improve the role of NGOs in state and public life. 
In 2017, the non-governmental non-profit organization MA provided $660 \mathrm{mln}$. soums, in 2018 - $780 \mathrm{mln}$. soums, in 2019 - $700 \mathrm{mln}$. soums, and in $2020-1,500 \mathrm{mln}$. UZS received a state subsidy. Today, more than 660 non-governmental non-profit organizations are members of the Uzbek NGO, and systematic cooperation has been established with them.

During 2017-2020, the Uzbek NGO organized 5 forums of large non-governmental non-profit organizations and provided practical assistance in organizing 6 forums.

In our opinion, the following systemic problems are observed in the effective functioning of the Association:

1. The system of non-governmental non-profit organization MA does not have an effective system of personnel policy. As a result of low salaries of employees of nongovernmental non-profit organizations, qualified and specialized specialists are almost not involved in non-governmental organizations.

2. There are no structural subdivisions and potential employees of the NGO, which is aimed at preparing systematic and analytical data on the development trends of nongovernmental non-profit organizations and the effective protection of the rights of nongovernmental non-profit organizations.

3. Insufficient logistical support of the Association. Also, due to the fact that the regional branches of the Uzbek NGO do not have the status of a legal entity, they do not have the material and technical resources.

4. Parliamentary Commission on Management of the Public Fund for Support of Non-Governmental Organizations and Other Civil Society Institutions under the Oliy Majlis of the Republic of Uzbekistan, Jogorku Kenesh of the Republic of Karakalpakstan, Public Commissions for Social Partnership under Regional and Tashkent City Councils and the Public Chamber and its non-inclusion in regional public chambers has a negative impact on the support of NGOs and the effective representation of their interests in these systems.

5. The Association has done almost no work to protect the rights and interests of non-governmental non-profit organizations. Also, there is no direct responsibility for obstructing or interfering with the legal activities of non-governmental non-profit organizations, and the legal basis for the Association's procedural participation in this process has not been strengthened.

6. Based on the mechanisms of incentives for non-governmental non-profit organizations to join the Association and the interests and rights of non-governmental non-profit organizations on draft laws, there is no institution of non-governmental sector representation in Parliament.

7. The practice of systematic monitoring of cooperation between public administration and local government with non-governmental non-profit organizations and the observance of the rights and interests of non-governmental non-profit organizations is not established.

The Association offers the following to support non-governmental non-profit organizations:

1. Increasing the number of staff units and the amount of their salaries of the central office and territorial subdivisions of the non-governmental non-profit organization, as well as increasing the amount of state subsidies to the Association, provided for the allocation of additional funds for material and technical base. 
2. The Parliamentary Commission on Management of the Public Fund for Support of Non-Governmental Organizations and Other Civil Society Institutions under the Oliy Majlis of the Republic of Uzbekistan, the Upper palate of the Republic of Karakalpakstan, Public Commissions on Social Partnership under the Regional and Tashkent City Councils and inclusion in the Public Chamber and regional public chambers.

3. Establish administrative liability for obstruction or interference with the lawful activities of non-governmental non-profit organizations and strengthen the legal framework for the National Association of Non-Governmental Organizations, including the courts, and other procedural participation in this process on the example of the Chamber of Commerce and Industry.

4. To submit to the Cabinet of Ministers in accordance with the established procedure a draft law on amendments and additions to the Tax Code on the provision of benefits from taxes and fees to members of influential national associations uniting civil society institutions.

5. Introduce the institution of permanent representative of non-governmental nonprofit organizations in the chambers of the Oliy Majlis.

6. On the basis of annual reports of the State Non-Governmental Organization on cooperation between state bodies and non-governmental non-profit organizations, state rights and local authorities in the Chambers of the Oliy Majlis and the Upper palate of the Republic of Karakalpakstan, regional and Tashkent city palates of People's Deputies strengthening the legal framework for discussing the work done in this direction by.

\section{REFERENCES:}

1. Address of the President of the Republic of Uzbekistan to the Oliy Majlis. January $20,2020$.

2. Koroleva L.P. Problems and proposals on the qualification status of socially oriented non-profit organizations in the quality of taxpayers // Taxes and financial law. 2011. - №. 6. - PP. 192-196.

3. Selected provisions from world practice on the procedure for granting organizations the status of charitable public benefit and exempt from taxation. Collection of materials. // ICNL. Almaty 2008. - P. 10.

4. Selected provisions from world practice on the procedure for granting organizations the status of charitable public benefit and exempt from taxation. Collection of materials. // Mejdunarodnyy tsentr Nekommercheskogo prava. Almaty 2008. p. -11.

5. Nemgirova S.N. Potential development of socially oriented non-commercial organizations as postmenshcheshno poleznyx uslug // Bulletin of the institute of complex studies of arid territories. - 2017. - T. 1. - №. 1 (34).

6. Guseynov E.K. Non-commercial organizations in the sphere of social protection: perspectives of development and problems of state support // Discussion. - 2013. - № 11. (41).

7. Sigidaeva A.V., Koropets A.A., Pavlova V.S. Analysis of the foreign taxation of nonprofit organizations // Problems of enterprise development: theory and practice. - 2019. - № 1-3. - PP. 126-130.

8. Mixeeva E.M., Peshkova N.N. Status of benevolent organizations in the structure of the region. -2012 .

9. Goncharenko L.I. Taxation of non-commercial organizations. - 2017.

10. Morris D., Unit C.L. How Does the Common Law Assess Public Benefit in Order to Define a Charity // International Journal for Not-for-Profit Law. - 1999. - T. 2. 
11. Selected provisions from world practice on the procedure for granting organizations the status of charitable, public organizations and exempt from taxation. Collection of materials. // ICNL. Almaty 2008. - P. 16.

12. Borovkova Yu.I. Charity and sponsorship // Bulletin of the scientific community of students, postgraduates and young scientists. - 2018. - №. 2. - PP. 19-25.

13. Law "On legal litsax with non-commercial tselyami".

14. Selected provisions from world practice on the procedure for granting organizations the status of charitable public benefit and exempt from taxation. Collection of materials. // ICNL. Almaty 2008. - P. 20.

15. National Database of Legislation, April 17, 2020, No. 06/20/5980/0450.

16. Sh.A. Saydullaev. Society is the initiator of reforms. // July 15, 2020. People's word No. 14.

17. Sh. Yakubov. Legal mechanisms of cooperation between state and civil society institutions / Monograph. - T.: LESSON PRESS Publishing House, 2018. - P. 96.

18. Haque M.S. Governance based on partnership with NGOs: implications for development and empowerment in rural Bangladesh // International Review of Administrative Sciences. - 2004. - T. 70. - №. 2. - PP. 271-290.

19. Bräutigam D.A., Segarra M. Difficult partnerships: The World Bank, states, and NGOs // Latin American Politics and Society. - 2007. - T. 49. - №. 4. - PP. 149-181.

20. Willetts P. From "consultative arrangements" to "partnership": The changing status of NGOs in diplomacy at the UN // Global Governance: A Review of Multilateralism and International Organizations. - 2000. - T. 6. - №. 2. - PP. 191-212.

21. Millar C.C.J.M., Choi C.J., Chen S. Global strategic partnerships between MNEs and NGOs: Drivers of change and ethical issues // Business and Society Review. - 2004. - T.: 109. - №. 4. - PP. 395-414.

22. Matiboev T.B. The system of social partnership in Uzbekistan: formation, development and prospects. - T., Academy. - 2014. - P. 10.

23. http://parliament.gov.uz/upload/iblock/cb3/srsiefppozktkk.pdf.

24. Sh. Yakubov. Legal mechanisms of cooperation between state and civil society institutions / Monograph. - T.: LESSON PRESS Publishing House, 2018 - P. 114.

25. https://uza.uz/oz/politics/zbekiston-respublikasi-prezidenti-shavkatmirziyeevning-oliy-25-01-2020.

26. Sh. Yakubov. Legal mechanisms of cooperation between state and civil society institutions / Monograph. - T.: LESSON PRESS Publishing House, 2018 - P. 123.

27. Saidov A.X. Civil society institutions are on the rise. 08.05. 2020. // UzA official website: http://uza.uz/oz/society/fu-arolik-zhamiyati-institutlari-yuksalish-bos-ichida08-05-2018.

28. Karimova M. It is necessary to take a serious approach to the issues of social partnership // Socio-political newspaper “Jamiyat”. - 2016. - № 87.

29. Sh. Yakubov. Legal mechanisms of cooperation between state and civil society institutions / Monograph. - T.: Lesson press Publishing House, 2018 - PP. 125-29.

30. Сафарова X. Совершенствование конституционно-правовых гарантий обеспечения права граждан на квалифицированное медицинское обслуживание в Узбекистане // Reviewoflawsciences. - 2020. - T. 5. - №. Спецвыпуск. 
31. Якубов Шухрат Правовые механизмы сотрудничества государственных и неправительственных организаций в Узбекистане: сравнительно-правовой анализ // Журнал зарубежного законодательства и сравнительного правоведения. 2018. №6 (73). URL: https://cyberleninka.ru/article/n/pravovye-mehanizmy-sotrudnichestvagosudarstvennyh-i-nepravitelstvennyh-organizatsiy-v-uzbekistane-sravnitelnopravovoy-analiz (дата обращения: 27.05.2021).

32. Ихтиёр Беков Деятельность парламента во время пандемии: опыт зарубежных стран и Узбекистана // Review of law sciences. 2020. №2. URL: https://cyberleninka.ru/article/n/deyatelnost-parlamenta-vo-vremya-pandemii-opytzarubezhnyh-stran-i-uzbekistana (дата обращения: 27.05.2021).

33. Bekzod M. Problems occurring in organization of private employment agencies' activities in ensuring employment of the population and their solutions // "Хуқуқий тадқиқотлар" электронжурнали. - 2020. - Т. 4. - №. 5.

34. Kosimov Botirjon Ma'rufjon o'g'li Threats to judicial independence: reflections on the us experience // TSUL Legal Report. 2020. №1. URL: https://cyberleninka.ru/ article/n/threats-to-judicial-independence-reflections-on-the-us-experience (дата обращения: 27.05.2021).

35. Нариманов Б., 2020. Ўзбекистонда нодавлат нотижорат ташкилотлар тарихи ва ривожланишининг асосий тенденциялари. юрист ахборотномаси, 1(3), PР. 18-29.

36. Алиева К.Р. Парламентда гендер тенглиги масалалари: Ўзбекистон ва хорижий мамлакатлар мисолида // Журнал правовых исследований. - 2020. №. Special 2. 